brazilianpoliticalsciencereview

BOOK REVIEW

\title{
Post-Western World*
}

\author{
by Augusto Leal Rinaldi \\ Universidade de São Paulo, São Paulo, São Paulo, Brazil
}

(Stuenkel, Oliver. Post-Western World: how emerging powers are remaking global order. Malden: Polity Press, 2016)

The contemporary world order is under intense scrutiny from observers, specialists, and researchers of the subject. Since the 2000s, a period that witnessed the emergence of developing countries onto the international scene, we have been seeing a growing interest in the study of the relations between the traditional powers and rising powers, as well as their effects on the global system. Such an interest can be illustrated by the recent publishing of impactful work such as Kissinger (2014), Acharya (2014), Ikenberry (2014), and Allison (2017), among others. Despite the differences in theoretical conceptualizations and their diagnosis of the situation, they have in common a critical look at the underlying logics of the structure and functioning of the current global order. In addition, all of them consider - and disagree on - future prognostics about world politics.

In the field of International Relations, the objects of investigation that fit within the perspective of systemic analysis are generally studied through one of two main approaches: one that centers on researching the implications on the system of transformations and changes in the nature or composition of the world order (KUPCHAN et al., 2001; MEARSHEIMER, 2001; MODELSKI, 1987) with the other looking to identify and explain the main causes of these changes when they occur (GILPIN, 1981;

(*) http://dx.doi.org/10.1590/1981-3821201800010008

This publication is registered under a CC-BY Licence. 
IKENBERRY, 2014; TERHALLE, 2015) ${ }^{1}$. In this context, we can state, without a doubt, that 'Post-Western World' (2016), by Oliver Stuenkel, generates thought-provoking insights not only about the current configuration of the world order, but also about the traits that it could have in the future. As such, his book freely and coherently moves between these two approaches by offering the reader a significant amount of material to understand and problematize while exploring the dynamics present in a world that is currently in metamorphosis.

Stuenkel is currently Professor of International Relations at the Getúlio Vargas Foundation and has been dedicating himself to studying topics related to the contemporary international politics and foreign relations of Brazil. His intellectual production, which encompasses academic articles, newspaper and magazine editorials, and books, has studied, among other topics, the political formation and coordination of groups of countries such as IBSA (STUENKEL, 2014) and the BRICS (STUENKEL, 2015a), the challenges of Brazilian foreign policy (STUENKEL and TAYLOR, 2015b), and, most recently, the current and future contours of the post-Western world order (2016). I made the choice to review this last work because of the originality of the ideas it brings to light and its potential to engender significant changes in how we see and study today's world. This will be clear to us if we look at the central thesis proposed by the author: that the way in which a good part of analysts tend to treat the current world order is guided by a 'parochial Western-centric' vision, which generates profound limitations when it comes to understanding the historical role played by non-Western powers in constructing that order, such as underestimating that role in the present day and the near future.

It is under this premise that the work advances its reflections. Derived from this proposition, a message that echoes throughout the entire book is that the referential lens through which we observe and analyze the world order needs to be adjusted. The studies that discuss this topic, therefore, deduce from that parochial vision a focus that normatively divides the universalist and modern West from the particularist and traditional non-West. Up to now, non-Westerners, when evaluated through this

1 The approaches are different primarily in how they look at the object of investigation: the former sheds light on the various implications that changes in the international power hierarchy cause in the structure of the international system; the latter, in turn, starts form the assumption hat there are structural changes, and that the task is therefore to identify and theorize about the main causes of these transformations, regardless of the impact they are causing. 
'civilizational bias' (HUNTINGTON, 1993), are perceived as relatively passive in international society, and rarely as legitimate constructors of rules and institutions of global governance. Stuenkel (2016) defends that it is necessary for us to overcome this predominantly Western vision and offer an alternative perspective. In this perspective, the role of actors such as the U.S., China, Europe, China, India, and Brazil are enmeshed in a relational logic in which the construction of the order, with clearly multipolar traits, would depend, to a great degree, on the reconciliation and accommodation of rivalries and interests among these powers. Regarding what he says about the two biggest powers (i.e., the U.S. and China), both would establish a type of 'asymmetric bipolarity' that would be the central axis of the structure and shape of this post-Western world.

The book is divided into six chapters in addition to an introduction and a conclusion. It follows a coherent order that mixes descriptive and analytic tools for the topics that each section looks to discuss. The first chapter, 'The Birth of WesternCentrism', centers its attention on the process of the West's ascension and the quality of hegemonic civilization, but with the caveat that this process was not endogenous, and did not mark the definitive beginning of the international system that we know today. Stuenkel (2016) reflects on how, before the West took the lead in the construction of this system, other non-Western countries and civilizations had large and notable roles in this process. By the way, it is this that is meant by the term 'Western world', that is, the leadership of a small group of Western countries in the development of global rules and norms. He questions, for example, the idea that the great voyages of the $15^{\text {th }}$ and $16^{\text {th }}$ centuries and the Treaty of Westphalia (1648) are the greatest milestones originating from this system. He argues that, beforehand, great civilizations such as the Chinese, Hindus, and Persians were already establishing commercial relations that put them in direct contact and, in turn, created their own rules and norms that were accepted and followed by them. The West, then, is the beneficiary and heir of this pre-Western system.

Instead of considering the rise of the West from the bias that emphasizes factors that are characteristic of European civilization as conditions for that rise, Stuenkel (2016) responds that it would be more appropriate to see the rise as a combination of factors that produced a window of opportunity for Europe to be successful. Such a 
window would incorporate the relative decline of Asian economic growth ${ }^{2}$, the privileged access of Europeans to the abundant resources of their colonies and the Americas, the exploitation of African and native slaves, a high military capacity, and the development of a system of states capable of integrating innovation and industrialization. One can notice, with this, Stuenkel's integrative theoretical conceptions for approaching international relations - derived, therefore, from the perspective of Global History.

The second chapter, 'Power Shifts and the Rise of the Rest', discusses the processes of change and transformation of systemic power and the role of emerging countries ('the rest'). The focus rests, for the most part, on the economic and military elements of power. The context in the background is the post-World War II international order led by the U.S., and it includes the most up-to-date studies about projections regarding the role of China as a leading player. In this section, Stuenkel (2016) makes an important exception to the title of the book: the post-Western world refers to the coming of the end of an uncommon (and unnatural) concentration of economic and military power accumulated by the West over the last two centuries that has allowed it to lead the world order. The 'post-Western' adjective, in this sense, should be understood not as the total subversion of the values, rules and norms commonly - if erroneously - associated exclusively with the West, but with a situation in which the structural axis, leadership - the defining component of these rules and norms - will no longer be centered solely on Western figures. Non-Western powers, in particular China, will play a role of equal (or even greater) relevance. The world is about to witness, therefore, a 'post-Westernness' in the sense of its normative and structural workings, in which the addition of new players will lead to the establishment of new dynamics and power relations.

China is the protagonist 'par excellence' in this chapter — in the entire book, in fact. The long period of Chinese economic growth has been producing a systemic impact that, according to projections, will be long-term. The post-Western order will be marked, therefore, by an asymmetric bipolarity in which the U.S. will continue being, by far, the great military power, but will have to deal with a perspective in which, in less than two decades, China will be the main global economic power. This economic multipolarity

${ }^{2}$ China, for example, until the middle of the 19th century, was the largest economy in the world (cf. STUENKEL, 2016).

(2018) $12(1) \quad$ - $\quad$ e0008-4/8 
raises three questions for analysts: 01 . What will this new order look like? 02 . Will this new order be durable? 03. Will this new order be peaceful? Stuenkel (2016) offers some responses that deserve attention.

'The Future of Soft Power' conducts the discussion of the third chapter. The potential and constraints of the economic and military rise of China guide the ability to transform elements of hard power into soft power. Invoking the classic term coined by Harvard University Professor Joseph Nye Jr. (1990), Stuenkel points (2016) out the conceptual limitations of our vocabulary for evaluating emerging countries. Even though the Western powers have maintained, up to this moment, their wide advantage over non-Western powers in this area, there are some initiatives headed by non-Western powers that have been helping them learn and gain prominence in this sense. Stuenkel (2016) mentions, among others, the Brazilian proposition of the 'Responsibility while Protecting' principle in the UN General Assembly and the Chinese contributions in peacekeeping missions and anti-pirating operations in the Indian Ocean.

Chapters 04 and 05, titled 'Toward a Parallel Order: Finance, Trade and Investment', and 'Toward a Parallel Order: Diplomacy, Security and Infrastructure', respectively, follow a continued and cohesive line of argument. These two sections have the goal of showing, exhaustively even, the vast field of initiatives and institutions headed by emerging powers. Furthermore, Stuenkel (2016) looks to explore the potential impact that they could come to have on the structure of the post-Western world. This display of proactiveness, Stuenkel (2016) observes, is about to create a 'parallel order' that is tending to reduce the appeal of existing Western institutions. Continuing to counter the 'alarmists' and 'skeptics', Stuenkel (2016) argues that nonWestern powers will continue to invest in Western structures and pressure for more reforms. Nevertheless, at the same time, they will expand their own network in order to present themselves, quickly, as being ready to engage in new institutions and even looking to increase autonomy from Western powers ${ }^{3}$.

These chapters, just like the entire book, are full of examples. For those who are interested, there are thought-provoking (and overly optimistic, in my judgment) analyses about the challenges and potential of the Asian Infrastructure Investment Bank

${ }^{3}$ I would be remiss not to cite a passage from Amitav Acharya that humorously illustrates this idea: "Although the American show may continue to dominate the box office for a while, the audience may lose interest when faced with more choices" (ACHARYA, 2014, p. 08).

(2018) $12(1) \quad$ a $\quad$ e0008-5/8


(AIIB), New Development Bank (NDB), Chiang Mai Initiative, Shangai Cooperation Organization (SCO), Brazil, Russia, China, India and South Africa (BRICS), One Belt One Road Initiative (OBOR), and others.

The last chapter, which even has the name of the book, 'Post-Western World', contains a summary of the arguments, but with the addition of a controversial thesis. The reasoning is developed as follows: this parallel order is not coming about because China and other non-Western powers are presenting fundamentally new ideas for solving global problems or because they intend to subvert the existing logic. On the contrary, this order is being created because these powers long to project their power with greater pragmatism, even emulating the Western powers themselves. Stuenkel (2016) emphasizes that a good part of the explanation for these initiatives rests with the limited mobility of the current order to adapt to rising powers. Existing institutions, as a consequence, do not integrate them adequately. As such, part of the strategy will be to continue to invest in these institutions, but while simultaneously looking to modify the international hierarchy of power in order to obtain privileges that, as of now, are enjoyed by the U.S.. Stuenkel (2016) provides an example of this that is worth remembering: the British and American intervention in Iraq in 2003. In other words, China and other non-Western powers are bestowing upon themselves the prerogative to break the rules when necessary.

As such, the critical point is that Stuenkel (2016) argues that emerging powers will demand special treatment in the post-Western world, which includes not adhering to the rules and norms when their national interests demand it. China, the exemplar of these powers, will seek 'global exceptionalism', which would look like the U.S.'s conduct when its foreign policy objectives are constrained. Lesser powers, in contrast, will shoot for this on a smaller 'regional' scale. This is happening as a result of their increase in national power, and consequently, a change in how they define their interests. In order to 'legitimate' these transgressions, these countries will have to offer more and more global public goods in the areas of security and economics as a counterweight. In Stuenkel's words, "...China and other emerging powers will carefully keep the balance between breaking the rules and providing public goods" (STUENKEL, 2016, p. 187). Non-Western powers, therefore, are no longer aspiring to live in a Western world order — and this is what that means: a world 'led' by the West - but in another world order, 
in which countries' roles are contingent, and the spaces in which countries can act increase in accordance with their empowerment.

As a result, Stuenkel (2016) infers that:

Emerging powers accept global order's liberal characteristics and are likely to maintain them, but they will change the hierarchy that undergirds the system. Aside from the new institutions created by emerging powers, several existing international institutions may not look that different several decades down the line, and neither with the norms and rules they are based on. Yet while today it is the United States that can break the rules and go unpunished, this privilege will soon be China's and possibly one day that of other emerging powers. There is no evidence that they will use it any differently than the United States has over the past decades (STUENKEL, 2016, p. 193).

Finally, the conclusion resumes the argument of the book, looking to summarize the central points and show some implications of its analysis for the field of policy. It describes certain dynamics that could become important for the future world order, and underlines the necessity of adapting one's analytic perspectives to a truly multipolar reality. Following this, he concludes that we must adapt a post-Western vision that integrates the distinct facets of the international order without neglecting the whole and overestimating the particular.

The book has the merit of proposing an analysis that, first of all, confronts the dominant current of thought in the West that looks at the process of multipolarization with skepticism or pessimism, or as a threat. Second, it presents a theoretical perspective that is hardly ever used in the Western International Relations literature to frame and study the relation between the world order, rising powers, and periods of systemic transition. Third, it moves the lens of analysis toward the role of non-Western powers in the current structure of the system, yet without neglecting the limits of this approach. Fourth, it supplies important analytic material for instrumentalizing specific policies with respect to certain topics and questions on the international agenda. Lastly, the book suggests some research agendas: how to think about the international system through a Global History perspective; the contributions non-Western countries offer to the rising new order; and the implications of multipolarity for matters of peace and international security. As with every notable work, however, 'Post-Western World' goes beyond the few words permitted in this review. 
Translated by Ryan Lloyd

\section{References}

ACHARYA, Amitav (2014), The end of American world order. Malden: Polity Press. 96 pp..

ALLISON, Graham (2017), Destined for war: can America and China escape Thucydides's trap? Boston: Houghton Mifflin. 389 pp..

GILPIN, Robert (1981), War and change in world politics. Cambridge: Cambridge University Press. 288 pp..

HUNTINGTON, Samuel P. (1993), The clash of civilizations? Foreign Affairs. Vol. 73, № 03, pp. 22-49.

IKENBERRY, G. John (Ed) (2014), Power, order, and change in world politics. Cambridge: Cambridge University Press. 308 pp..

KISSINGER, Henry (2014), World order: reflections on the character of nations and the Course of History. London: Penguin Books. 432 pp..

KUPCHAN, Charles A.; ADLER, Emanuel; COICAUD, Jean-Marc, and FOONG, Yuen (2001), Power in transition: the peaceful change of international order. New York: United Nations University Press. 300 pp..

MEARSHEIMER, John J. (2001), The tragedy of great powers politics. New York: W.W. Norton \& Company. 355 pp..

MODESLKI, George (1987), Long cycles in world politics. Seattle: University of Washington Press. 244 pp..

NYE JR., Joseph (1990), Soft power. Foreign Policy. Vol. 80, pp. 153-171.

STUENKEL, Oliver (2015a), The BRICS and the future of global order. Maryland: Lexington Books. 268 pp..

STUENKEL, Oliver and TAYLOR, Matthew M. (Eds) (2015b), Brazil on the global stage: power, ideas, and the liberal international order. New York: Palgrave McMillan. 228 pp..

STUENKEL, Oliver (2014), India-Brazil- South Africa Dialogue Forum (IBSA) (2014), Rise of the Global South. London, New York: Routledge Global Institutions. 198pp..

TERHALLE, Maximilian (2015), The transition of global power: legitimacy and contestation. New York: Palgrave McMillan. 267 pp.. 